\title{
1 ADAR1 editing dependency in triple-negative breast cancer
}

2

3 Che-Pei Kung ${ }^{1,3}$, Kyle A. Cottrell ${ }^{1,3}$, Sua Ryu ${ }^{1}$, Emily R. Bramel ${ }^{1}$, Raleigh D. Kladney ${ }^{1}$, Emily

4 A. Bross ${ }^{1}$, Leonard Maggi Jr. ${ }^{1}$ and Jason D. Weber ${ }^{1,2,4,^{*}}$

$5 \quad{ }^{1}$ Department of Medicine, Division of Molecular Oncology and ${ }^{2}$ Department of Cell Biology and

6 Physiology, Siteman Cancer Center, Washington University School of Medicine, Saint Louis,

7 Missouri, USA

8

$9 \quad{ }^{3}$ These authors contributed equally

$10{ }^{4}$ Lead Contact

$11 *$ Correspondence: jweber@wustl.edu 


\section{Summary}

Triple-negative breast cancer (TNBC) is the deadliest form of breast cancer. Unlike other

16 types of breast cancer that can be effectively treated by targeted therapies, no such targeted

17 therapy exists for all TNBC patients. The ADAR1 enzyme carries out A-to-I editing of RNA to

18 prevent sensing of cellular double-stranded RNAs (dsRNA). ADAR1 is highly expressed in

19 breast cancer including TNBC. Here, we demonstrate that ADAR1 expression and editing

20 activity is required in TNBC cell lines but not in ER+ and/or Her2+ cells. In TNBC cells,

21 knockdown of ADAR1 attenuates proliferation and tumorigenesis. PKR expression is elevated in

22 TNBC and its activity is induced upon ADAR1-knockdown, which correlates with a decrease in

23 translation. ADAR1-dependent TNBC cell lines also exhibit elevated IFN stimulated gene

24 expression. IFNAR1 reduction significantly rescues the proliferative defects of ADAR1 loss.

25 These findings establish ADAR1 as a novel therapeutic target for TNBC tumors.

27 Keywords: ADAR1, triple-negative breast cancer, RNA editing, Type I IFN, PKR 


\section{Introduction}

Generally defined by the lack of estrogen receptor (ER), progesterone receptor (PR) and HER2 expression, triple-negative breast cancer (TNBC) accounts for 15 to 20 percent of all breast cancer diagnoses in the United States each year(Ademuyiwa et al., 2017). Unlike ERpositive (tamoxifen, fulvestrant, and other ER modulators) and HER2-positive (Herceptin and other HER2 inhibitors) breast cancers, there are no targeted therapies for all TNBC patients(Waks and Winer, 2019). The lack of targeted therapies for TNBC leaves chemotherapy as the main treatment option that carries a generally worse prognosis(Garrido-Castro et al., 2019). Efforts to develop effective targeted therapies against TNBC have focused on further subcategorizing TNBC based on gene expression signatures, as well as looking to exploit common genetic vulnerabilities(Perou, 2011, Anders et al., 2016).

A potential therapeutic target for TNBC is Adenosine Deaminase Acting on RNA (ADAR1, encoded by $A D A R$ ). ADAR1 caries out the enzymatic reaction of deaminating adenosine to inosine within cellular dsRNA, in a process known as A-to-I editing. Induction of ADAR1 expression is prevalent in breast cancer(Fumagalli et al., 2015, Han et al., 2015, PazYaacov et al., 2015, Peng et al., 2018, Anantharaman et al., 2017) and ADAR1-mediated A-to-I editing has been found to influence the levels of its targets in breast cancer(Gumireddy et al., 2016, Binothman et al., 2017, Dave et al., 2017, Nakano et al., 2017). Recent studies indicate that ADAR1 is over-represented in TNBC and may be correlated with poor prognosis when RNA editing is increased(Song et al., 2017, Sagredo et al., 2018).

ADAR1 acts in a negative feedback loop to inhibit the type-I IFN pathway triggered by endogenous dsRNAs or dsRNAs introduced upon viral infections(Mannion et al., 2014, Liddicoat et al., 2015). ADAR1 has been shown to suppress type-I IFN pathway through 
52 multiple mechanisms, including destabilization of the dsRNA structure, reduced expression, and

53 activation of the dsRNA sensors MDA5 and RIG-I, and inhibition of IFN expression(Mannion et

54 al., 2014, Liddicoat et al., 2015, Pestal et al., 2015, George et al., 2016, Li et al., 2012, Pujantell

55 et al., 2017). ADAR1-mediated A-to-I RNA editing by the IFN-inducible p150 isoform (not the

56 constitutive p110 isoform) is essential for its ability to modulate dsRNA-induced IFN

57 signaling(Liddicoat et al., 2015, Pestal et al., 2015, George et al., 2016). ADAR1's ability to

58 regulate this response was recently linked to the development of ADAR1 dependency in some

59 cancer cell lines; two groups showed that by removing ADAR1 from cancer cells with elevated

60 innate immune signaling, cells became susceptible to inflammation-induced cell death(Gannon et

61 al., 2018, Liu et al., 2019). This is consistent with previous findings that ADAR1 prevents

62 immune and translational catastrophes by blocking dsRNA-activated IFN pathway(Mannion et

63 al., 2014, Chung et al., 2018).

Here we demonstrate that TNBC cell lines are dependent on ADAR1 expression and

65 activity; loss of ADAR1 in these cell lines inhibits cellular growth and tumorigenesis,

highlighting the therapeutic potential of ADAR1 inhibitors for the treatment of TNBC.

\section{Results}

\section{ADAR1 is highly expressed in all breast cancer subtypes}

Using publicly available data from TCGA (The Cancer Genome Atlas)(Han et al., 2015,

71 of breast cancers (Figure 1A). Recent studies indicated that ADAR1 promotes tumorigenesis of

72 metaplastic breast cancers, and that high expression of ADAR1 correlates with poor prognosis in

73 basal-like breast cancers(Sagredo et al., 2018, Dave et al., 2017). Since both basal-like and 
metaplastic breast cancers share similar characteristics with TNBC, we sought to determine the importance of ADAR1 in the tumorigenesis of TNBC. By evaluating the TCGA database, we found that while mRNA expression of ADAR1 was higher in TNBC compared to normal, it was not significantly different between TNBC and non-TNBC tumors (Figure 1B). Additionally, ADAR1 expression was not significantly higher in any one subtype of breast cancer based on PAM50 classification(Lehmann et al., 2016) (Supplemental Figure 1A). This observation is consistent with data from the Cancer Cell Line Encyclopedia (CCLE), which uses both RNA-seq and Reverse Phase Protein Array (RPPA) to determine RNA and protein expression levels in numerous cancer cell lines (Supplemental Figure 1B-C). Data from both the TCGA and CCLE datasets also revealed that both p150 and p110 isoforms of ADAR1 were expressed at similar levels between TNBC and non-TNBC specimen (Supplemental Figure 1D-H), with p110 expression being consistently higher than p150 in all samples. Additionally, we assessed p150 isoform expression by immunohistochemistry in TNBC and non-TNBC patient tumors, Figure 1D. We sought to determine the protein expression level of the ADAR1-p150 isoform in a panel of established breast cancer cell lines representing TNBC and non-TNBC. Immunoblot analysis showed that ADAR1 (p150 isoform) is overexpressed, compared to normal human mammary epithelial cells (HMECs), in over half of all TNBC (6/8) and non-TNBC (5/8) cell lines assayed (Supplemental Figure 1I-K). These results indicate that ADAR1-p150 is overexpressed in many breast cancer cell lines regardless of subtype.

\section{ADAR1 is required for TNBC proliferation}

Several recent studies have suggested that some established cancer cell lines display strong dependencies on ADAR1 expression(Liu et al., 2019, Ishizuka et al., 2019, Gannon et al., 2018). Given the high expression of ADAR1-p150 in most breast cancer cell lines, we sought to 
97 determine whether these breast cancer cell lines exhibited ADAR1-dependency. We analyzed

98 publicly available RNAi and CRISPR-Cas9 datasets to determine if ADAR1 was required for the

99 survival of breast cancer cell lines representing various subtypes(McFarland et al., 2018, Meyers

100 et al., 2017). TNBC and basal-like cell lines made up the majority of breast cancer cells

101 exhibiting high ADAR1 sensitivity scores (DEMETER2 Score < -0.5) (Figure 1C, Supplemental

102 Figure 2A-C). Importantly, we did not observe a correlation between ADAR1 expression and 103 ADAR1-dependency across these breast cancer cell lines (Supplementary Figure 2D). To 104 experimentally validate ADAR1-dependency among breast cancer cell lines, we knocked-down 105 ADAR1 expression in eight cell lines (Four TNBC: MDA-MB231, MDA-MB468, BT549, 106 noticeable ADAR1-p150 isoform overexpression over HMEC controls in our immunoblot analysis (Supplemental Figure 1I). Long-term (7-28 days) and short-term (4 days) cell proliferation was evaluated for each cell line following ADAR1 knockdown. Notably, similar levels of ADAR1 knockdown were achieved for each cell line (Figure 1E). All four TNBC cell

111 lines displayed significant attenuation in both long- and short-term proliferation following 112 ADAR1 knockdown (Figure 1F-G, Supplemental Figure 2E). Conversely, ADAR1 expression 113 proved dispensable for proliferation in all four non-TNBC cell lines.

\section{ADAR1-p150 editing activity rescues TNBC proliferation}

While both isoforms of ADAR1 are expressed in TNBC, our knockdown experiment does not distinguish between p150 or p110 dependence. To address this, we set up a knockdown-

117 rescue system. We overexpressed either the p110 or p150 isoform following ADAR1

118 knockdown in MDA-MB231 cells and evaluated their ability to rescue cell proliferation (Figure

119 1H-J). Overexpression of ADAR1-p150, but not p110, resulted in significant rescue of cell 
120

121

122

123

124

125

126

127

128

129

130

131

132

133

134

135

136

137

138

139

140

141

proliferation in MDA-MB231 TNBC cells. Having established a rescue system for ADAR1 dependent proliferation, we next aimed to determine whether the editing activity of ADAR1p150 was required for this rescue. An editing-defective mutant (E912A) of the p150 isoform was incapable of rescuing the ADAR1 knockdown phenotype, indicating that the A-to-I editing function of ADAR1 is absolutely required for cellular proliferation in TNBC cells (Figure 1I-J).

\section{ADAR1 is required for TNBC transformation and tumorigenesis}

To assess the functional relevance of our findings, we investigated the requirement of ADAR1 for the transformation of breast cancer cell lines. We utilized anchorage independent growth in soft agar as a measure of cellular transformation. Knockdown of ADAR1 dramatically reduced soft agar colonies of MDA-MB231 and HCC1806 TNBC cells while not significantly affecting the numbers of colonies formed by SKBR3 and T47D non-TNBC cells (Figure 2A-D).

To extend these in vitro findings, we next determined whether ADAR1 was required for TNBC cell lines to form tumors in vivo. We performed mammary gland orthotopic transplantations using TNBC and non-TNBC cells following ADAR1 knockdown. Parental (shRNA-NonTargeting, shNT) MDA-MB231 and MDA-MB468 TNBC cells and SKBR3 nonTNBC cells were all able to form visible tumors in the mammary glands of four-five independently transplanted female immune compromised mice (Figure 2E-H). Knockdown of ADAR1 in MDA-MB231 and MDA-MB468 TNBC cells completely abrogated their ability to form tumors in transplanted mice. In contrast, ADAR1 knockdown in SKBR3 cells did not significantly affect tumor formation in transplanted mammary glands. Collectively, these results demonstrate that ADAR1 expression is required for in vitro transformation and in vivo tumor formation of TNBC cells, but is completely dispensable for these properties in non-TNBC cells.

\section{PKR is overexpressed in TNBC and activated upon ADAR loss}


TNBC (Figure 3A). This is consistent with RNA-seq data for breast cancer cell lines within the

151 CCLE (Figure 3B). Moreover, elevated PKR expression positively correlates with the ADAR1

157 cells compared to non-TNBC cells. Upon ADAR1 knockdown, phosphorylation of PKR and cell lines (Figure 3E). These observations suggest that TNBC-associated ADAR1 dependency might be attributed to PKR-mediated translational inhibition. To investigate this, we performed polysome profiling. ADAR1 knockdown in MDA-MB231 and HCC1806 TNBC cells led to

162 inhibition of translation, demonstrated by the substantial reduction of polysome peaks (Figure 163 3F-G). These results suggest that translational repression contribute to TNBC-associated 164 ADAR1 dependency. While attempting to rescue the ADAR-knockdown phenotype in MDA- 
greatly reduced foci formation (Supplemental Figure 3D-E). This suggests basal PKR expression is required for the proliferation of these cell lines and precluding us from determining if expression of PKR is required for the ADAR-knockdown phenotype.

\section{RNASEL is not activated following loss of ADAR1 in TNBC}

Activation of RNASEL and subsequent translational inhibition has also been shown to result in cell lethality in the absence of ADAR1(Li et al., 2017). The CCLE dataset indicated that RNASEL activators OAS1, OAS2 and OAS3 were highly expressed in ADAR1 dependent cell lines, while the expression of RNASEL showed modest correlation with ADAR1 dependency (Supplemental Figure 3F-G). A hallmark of RNASEL activation is degradation of rRNA(Silverman et al., 1983). However, we did not observe rRNA degradation in ADAR1dependent TNBC cells after ADAR1 knockdown (Supplemental Figure 3H), further suggesting that the RNASEL pathway does not significantly contribute to TNBC-associated ADAR1 dependency and the induction of OAS genes likely reflects the fact that OAS genes are also known ISGs (see below).

\section{ADAR1-dependent TNBCs exhibit elevated ISG expression}

Another factor contributing to ADAR1 dependency in cancer cell lines is the type-I IFN pathway(Liu et al., 2019). It has been shown previously that this connection is mediated through either altering the expression of type I IFN regulators or activating the feed-forward loop of IFN signaling(Gannon et al., 2018, Liu et al., 2019). RNA expression data from the TCGA and CCLE datasets showed that TNBC have higher ISG expression (Core ISG Score(Liu et al., 2019)) compared to non-TNBC (Figure 4A-B). This is consistent with the elevated expression of PKR and ISG15 in our immunoblot analysis among breast cancer cell lines (Figure 3D, Supplemental 
Figure 4A). Like PKR expression, the Core ISG Score positively correlated with ADAR1 sensitivity among TNBC cell lines (Figure 4C and Supplemental Figure 4B-C).

\section{INFAR1 loss rescues ADAR1 knockdown phenotype}

To establish whether the type-I IFN pathway accounts for the significant differences of ADAR1-dependency between TNBC and non-TNBC cell lines, non-TNBC cell lines (SKBR3 and MCF7) were treated with IFN $\beta$ in ADAR1-intact and ADAR1-deficient cells (Supplemental Figure 4D-G). Expression of ADAR1 and ISG15 were induced upon IFN $\beta$ treatment, as well as phosphorylation of STAT1. However, while the treatment of IFN $\beta$ generally reduced cell proliferation, it did not sensitize non-TNBC cells to ADAR1 deficiency (Supplemental Figure 4E and G), implying that IFN $\beta$ alone is not capable of switching ADAR1-resistant cells to ADAR1dependent cells.

To determine if the type-I IFN pathway functionally contributes to ADAR1 dependency in TNBC, we knocked-down ADAR1 and the IFN alpha-receptor subunit 1 (IFNAR1) simultaneously in both MDA-MB231 and MDA-MB468 cells (Figure 4D and Supplemental Figure $4 \mathrm{H})$. The knockdown of IFNAR1 partially rescued the proliferation of both cell lines, suggesting that TNBC-associated ADAR1 dependency can be partially attributed to type I IFN pathway (Figure 4E-F, Supplemental Figure 4I). However, knockdown of IFNAR1 in TNBC cells did not alter the levels of phosphorylated PKR (Figure 4D, Supplemental Figure 4H), suggesting that in these TNBC cells, either type-I IFN and PKR pathways independently contribute to ADAR1 dependency or IFNAR1 resides downstream of PKR.

\section{Discussion}

Recent studies have highlighted the dependence of some cancer cell lines on ADAR1 expression(Gannon et al., 2018, Liu et al., 2019). Here, we characterized the requirement for 
ADAR1 in a panel of established breast cancer cell lines. ADAR1-dependent cell lines shared an

212

213

214

215

216

217

218

219

220

221

222

223

224

225

226

227

228 elevated ISG-expression signature. Loss of ADAR1 in these cell lines led to activation of the translational regulator PKR and translational repression. The ADAR1-dependence phenotype could be partially abrogated by knockdown of IFNAR1. It is not currently understood what makes select cancer cell lines ADAR1-dependent, or conversely why others are refractory to ADAR1-loss. It has been proposed that the higher ISG expression might potentiate these cells towards ADAR1-dependency - loss of ADAR1 would further elevate ISG expression leading to the growth inhibition phenotype(Liu et al., 2019, Gannon et al., 2018). However, we have demonstrated that for cell lines refractory to ADAR1 loss, treatment with IFN- $\beta$ did not render them sensitive to ADAR1 knockdown. Furthermore, we observed no activation of PKR in the ADAR1 refractory cell lines following ADAR1 loss. These findings suggest that the link between ADAR1 loss and the IFN pathway or PKR activation in ADAR1-refractory cell lines is missing. Loss of ADAR1 is thought to activate the IFN pathway and PKR by causing an increase in dsRNA - stemming from a reduction in A-to-I editing(Mannion et al., 2014, Liddicoat et al., 2015). It is possible that ADAR1-refractory cell lines either do not accumulate dsRNA following ADAR1 loss or there exists a system that prevents dsRNAs from activating the IFN pathway or PKR. Understanding the molecular basis of this process would help to predict which cell lines or more importantly which tumors - should be sensitive to ADAR1 loss.

Important clinical implications can be drawn from these observations. Our data suggest that ADAR1 is a legitimate candidate for targeted therapies in TNBC. We found that TNBC cell lines and patient samples exhibit elevated ISG and PKR expression, which is consistent with ADAR1-dependent cell lines. With increased understanding of ADAR1 functions, novel therapeutic strategies against ADAR1 could benefit ADAR1-dependent cancers, including 
234 TNBC(Kung et al., 2018). Secondly, the relationship between ADAR1 dependency and type-I

235 IFN pathway could point to new directions for TNBC interventions. Recent studies revealed that

236 the increased IFN $\beta$ target gene signature correlates with improved recurrence-free survival in

237 TNBC, and IFN $\beta$ treatment inhibits tumor progression in TNBC by reducing cancer stem cell

238 (CSC) plasticity(Doherty et al., 2017, Doherty et al., 2019). In addition to cell-intrinsic effects of

239 ADAR1-loss in cancer cells, removal of ADAR1 has been shown to sensitize tumors to

240 immunotherapy by overcoming resistance to checkpoint blockade(Ishizuka et al., 2019).

242 dormancy in ER-negative breast cancers, marked by sustained type-I IFN signaling, reduced cell

243 growth, and longer progression-free survival(Lan et al., 2019). This indicates a possible shared

244 mechanism between chemotherapy-induced immunological dormancy and ADAR1-dependency

245 in TNBC. It is important to note that careful considerations need to be given when applying the

246 concepts of ADAR1 inhibition and type-I IFN application in the treatment of TNBC. It is

247 recognized that type-I IFN can elicit paradoxical effects on cancer development(Snell et al.,

248 2017). For example, it has been suggested that type-I IFN pathway, potentially through ISG15-

249 mediated ISGylation, can promote the aggressiveness of TNBC(Forys et al., 2014, Lo et al.,

250 2018). Therefore, further understanding of the relationship between ADAR1 functions and

251 TNBC tumorigenesis should better inform the context in which this strategy can provide the

252 maximum benefit.

\section{Acknowledgments}

254 This work was supported by R01CA190986 (JDW), F32GM131514 (KAC) and TL1TR002344

255 (C-PK) from the National Institute of Health, and W81XWH-18-1-0025 from the Department of

256 Defense (JDW). This work was supported by the Longer Life Foundation: A RGA/Washington 
257 University partnership. The results shown here are in whole or part based upon data generated by

258 the TCGA Research Network: https://www.cancer.gov/tcga.

259 Author Contributions

260 Conceptualization, C-PK, KAC, and JDW; Methodology, C-PK, KAC, and JDW; Software,

261 KAC; Investigation, C-PK, KAC, SR, ERB, RK, EAB, LM, and JDW; Writing - Original Draft,

262 C-PK and KAC; Writing - Review \& Editing, C-PK, KAC, SR, ERB, RK, LM, and JDW;

263 Funding Acquisition, JDW; Supervision, JDW

264 Declaration of Interests

265 The authors declare no competing interests. 
Figure 1: ADAR1 is highly expressed in all breast cancer subtypes and required for TNBC proliferation

A) Kaplan-Meier survival curves of breast cancer patients. Patients were stratified by ADAR1 expression, above or below z-score $=2.34$. B) Relative mRNA expression of ADAR1 in normal, TNBC and Non-TNBC breast cancer. Data were extracted from TCGA database. C) ADAR1dependency scores in breast cancer cell lines. Lower DEMETER2 scores indicate stronger ADAR1-dependency. ERBB2 = HER2-positive. D) Representative images of IHC staining of ADAR1 in TNBC and Non-TNBC breast cancer tissues (scale: $100 \mu \mathrm{M}$ ). Numbers below the image indicate the ratio of samples identified as high p150-ADAR based on IHC scoring. $\mathbf{E}$ ) Immunoblots showing protein levels of ADAR1 p150 isoform and GAPDH(loading control) with or without ADAR1-knockdown in breast cancer cell lines. Fold change of ADAR1 (ShADAR1/ShNT) is indicated, normalized to GAPDH. Focus formation (FF) assay showed that ADAR1-knockdown reduced proliferation of TNBC but not Non-TNBC cells. Images are representative, $\mathrm{N}=3$. F) Quantification of $\mathrm{FF}$ in $\mathbf{E}$ ). Relative plate occupancy was determined using ImageJ software and normalized to ShNT samples for each cell line. Data are represented as mean $\pm \mathrm{SD}, \mathrm{N}=3$. G) Cell proliferation assay showing that ADAR1-knockdown reduced proliferation of TNBC but not Non-TNBC cells. Data are represented as mean $\pm \mathrm{SD}, \mathrm{N}=2$. $(* * * *) \mathrm{p}<0.0001$. ns, not significant. H) Immunoblots showing protein levels of ADAR1 and GAPDH(loading control) with overexpression of $\mathrm{p} 150, \mathrm{p} 110$ or editing-defective $\mathrm{p} 150^{\mathrm{E} 912 \mathrm{~A}}$ in ShADAR1-treated MDA-MB231 cells. Images are representative, N=3. EV, empty virus. I) FF assay showing that $\mathrm{p} 150$, but not $\mathrm{p} 110$ or editing-defective $\mathrm{p} 150^{\mathrm{E} 912 \mathrm{~A}}$, partially rescued proliferation of ShADAR1-treated MDA-MB231. Images are representative, $\mathrm{N}=3$. J) Quantification of FF in I). Relative plate occupancy was determined using ImageJ software and normalized to ShNT-EV. Data are represented as mean $\pm \mathrm{SD}, \mathrm{N}>3$. $(* *) \mathrm{p}<0.01$. n.s., not significant. See also Figure S1 and S2.

Figure 2: ADAR1 is required for TNBC transformation and tumorigenesis

A) Soft agar assay (SAA) showing that ADAR1-knockdown reduced anchorage-independent growth of TNBC cells (HCC1806 and MDA-MB231). Images are representative, N=3. Scalebar, $100 \mu \mathrm{M}$. B) Quantification of SAA in A). Colonies bigger than $100 \mu \mathrm{M}$ in diameter were counted. Data are represented as mean $\pm \mathrm{SD}, \mathrm{N}=3$. $(* * * *) \mathrm{p}<0.0001$. (**) $\mathrm{p}<0.01$. C) SAA showing that ADAR1-knockdown did not affect anchorage-independent growth of Non-TNBC cells (SKBR3 and T47D). Images are representative, N=3. Scale-bar, 100 $\mu$ M. D) Quantification of SAA in C). Colonies bigger than $100 \mu \mathrm{M}$ in diameter were counted. Data are represented as mean $\pm \mathrm{SD}, \mathrm{N}=3$. ns, not significant. E) Orthotopic implantation of MDA-MB231 cells into abdominal mammary fat pad. Tumors were removed from the mice $\sim 4$ weeks post injection and weighed (ShNT, N=4; ShADAR1, N=5). Red arrows indicate the location of mammary fat pad. F) Orthotopic implantation of MDA-MB468 cells into abdominal mammary fat pad. Tumors were removed from the mice $\sim 12$ weeks post injection and weighed $(\mathrm{N}=5)$. Red arrows indicate the location of mammary fat pad. G) Orthotopic implantation of SKBR3 cells into abdominal mammary fat pad. Tumors were removed from the mice $\sim 4$ weeks post injection and weighed $(\mathrm{N}=5)$. Red arrows indicate the location of mammary fat pad. H) Quantification of the result 
shown in E)-G). Data are represented as mean \pm SD. $(* * * *) p<0.0001 .(*) p<0.05$. ns, not significant.

\section{Figure 3: PKR is overexpressed in TNBC and activated upon ADAR loss}

A) Relative mRNA expression of PKR in TNBC and Non-TNBC. Data were extracted from TCGA database. B) Relative mRNA expression of PKR in ER-positive, ERBB2(HER2)-positive and TNBC cell lines. Data were extracted from CCLE database. C) ADAR1-dependency scores positively correlate with PKR expression. Upper panel: PKR expression z-score in breast cancer cell lines. Lower panel: ADAR1-dependency scores. Lower DEMETER2 scores indicate stronger ADAR1-dependency. D) Immunoblots showing protein levels of PKR, p-PKR (T446), p-eIF2 $\alpha$ (S51) and GAPDH(loading control) in breast cancer cell lines. Densitometry quantification of gel images was normalized to GAPDH and set relative to HMEC signal. Data shown are representative, $\mathrm{N}=3$. E) Immunoblots showing protein levels of PKR, p-PKR (T446), p-eIF2 $\alpha$ (S51) and $\beta$-tubulin (loading control) in TNBC and non-TNBC breast cancer cell lines with or without ADAR1-knockdown. Densitometry quantification of gel images was normalized to GAPDH and compared to HMEC signal set as 1 -fold. Data shown are representative, $\mathrm{N}=3$. F) Polysome profiling of MDA-MB231 cells with or without ADAR1-knockdown. Data shown are representative of three replicates. G) Ribosomal profiling of HCC1806 cells with or without ADAR1-knockdown. See also Figure S3.

Figure 4: ADAR1-dependent TNBCs exhibit elevated ISG expression and INFAR1 loss rescues ADAR1 knockdown phenotype

A) Relative ISG Core Scores in TNBC and Non-TNBC breast cancer samples. Data were extracted from TCGA database. B) Relative ISG Core Scores in ER-positive, ERBB2(HER2)positive and TNBC cell lines. Data were extracted from CCLE database. C) ADAR1dependency scores positively correlate with ISG Core Scores in breast cancer cell lines. Upper panel: ISG Core Scores in breast cancer cell lines. Lower panel: ADAR1-dependency scores. Lower DEMETER2 scores indicate stronger ADAR1-dependency. D) Immunoblots showing protein levels of IFNAR1, PKR, p-PKR (T446), p-eIF2 $\alpha$ (S51) and GAPDH(loading control) in MDA-MB231 cells. IFNAR1 was knocked down in ShADAR1-treated MDA-MB231 cells to determine if IFNAR1 loss reverses ADAR1-knockdown phenotype. Images are representative, $\mathrm{N}=3$. F) FF assay showing that IFNAR1 loss partially rescued ADAR1-knockdown phenotype in MDA-MB231 cells. Images are representative, $N=3$. G) Quantification of FF in F). Relative 


\section{Experimental Procedures}

\section{Cell lines and reagents}

Human mammary epithelial cells (HMEC) and breast cancer cells lines were obtained from American Tissue Cells Consortium (ATCC). HMECs were cultured in MammaryLife Basal Medium (Lifeline Cell Technology) and passaged by using 0.05\% trypsin-EDTA (Gibco) and Defined Trypsin Inhibitor (DTI, Gibco). All breast cancer cell lines were maintained in Dulbecco's Modification of Eagle's Medium (DMEM, GE Life Sciences) supplemented with 10\% fetal bovine serum (Gibco, 10091-148), Sodium Pyruvate (Cellgro, 30-002-CI), NonEssential Amino Acids (NEA, Cellgro, 25-030-CI), and L-glutamine (Cellgro, 25-005-CI). Lipofectamine 2000 (Invitrogen) was used for transfection to generate lentivirus. Fugene 6 transfection reagent (Roche) was used for all other transfection experiments.

\section{Immunoblot analysis}

Cell lysates were extracted from cells at $\sim 90 \%$ confluence. Cell were washed with phosphate-buffered saline (PBS, GE Life Sciences), scrape harvested, centrifuged at $1000 \times \mathrm{g}$ for 5 min, and lysed with RIPA buffer (20mM Tris-HCl pH7.5, 150mM NaCl, 1mM EDTA, 1\% NP40, 0.1\% SDS, 0.1\% Deoxycholate) supplemented with 10mM PMSF and HALT protease inhibitor cocktail (Thermo Fisher Scientific). Lysates were clarified by centrifugation and the protein concentration was determined using DC protein assay system (Bio-Rad Laboratories). Equal amount of protein was resolved by sodium dodecyl sulfate-polyacrylamide gel electrophoresis (SDS-PAGE) using Criterion TGX Stain-Free Precast Gels (Bio-Rad) and transferred onto Immobilon-P membranes (MilliporeSigma). Primary antibodies used in this study include ADAR1 (Santa Cruz, sc-73408), MDA5 (Cell Signaling, \#5321), RIG-I (Cell Signaling, \#3743), PKR (Cell Signaling, \#3072), PKR Thr-446-P (Abcam, ab32036), STING (Cell Signaling, \#13647), IFNAR1 (Bethyl Laboratories, A304-290A), ISG15 (Santa Cruz, sc- 
166755), GAPDH (Bethyl Laboratories, A300-641A), $\beta$-Tubulin (Abcam, ab6046), EIF2S1/eIF2 $\alpha$ Ser-51-P (Abcam, 32157), EIF2S1 (Abcam, ab5369). Secondary antibodies conjugated to Horseradish peroxidase were used at a dilution of 1:5-10,000 (Jackson Immunochemicals). Clarity Western ECL Substrate (Bio-Rad) was then applied to blots and protein levels were detected using autoradiography with ChemiDoc XRS+ Imager (Bio-Rad). Densitometry quantification of protein signals was performed using ImageJ software (NIH, Bethesda, MD).

\section{Quantitative reverse-transcription polymerase chain reaction}

Total RNA was isolated from cells using RNeasy Mini Plus kit (Qiagen, Hilden, Germany) including on-column DNase digestion following the manufacturer's protocol. High Capacity cDNA Reverse Transcription Kit (Life technologies, CA, USA) was used to transcribe RNA to cDNA. Quantitative PCR (qPCR) was performed using iTaq Universal SYBR Green Supermix (Bio-Rad, \#1725121) on the C1000 Thermal Cycler (CFX96 Real-Time System, BioRad), and data analysis was performed using the $2\left(-\Delta \Delta C_{T}\right)$ method. Messenger RNA expression levels were normalized to GAPDH. Primers used in this study are listed in Supplemental Table 1.

\section{Lentiviral production and transduction}

To generate lentivirus, transformed human embryonic kidney HEK293T cells were transfected using Lipofectamine 2000 (Invitrogen) with pCMV-VSV-G, pCMV- $\Delta$ R8.2, and expression constructs (with pLKO.1-puromycin or pLKO.1-hygromycin backbone for shorthairpin RNAs and with pLVX-hygromycin backbone for overexpression constructs). Growth medium was replaced with fresh medium $24 \mathrm{hr}$ after transfection, and supernatants containing lentivirus were harvested $24 \mathrm{hr}$ later. For transduction, one million cells were infected with 
388 lentivirus for $24 \mathrm{hr}$ in the presence of $10 \mu \mathrm{g} / \mathrm{ml}$ protamine sulfate to facilitate viral entry.

389 Sequences of shRNAs are listed in Supplemental Table 1. ADAR1 overexpression constructs

390 (p150; p110; p150-E912A mutant) were subcloned from pBac-ADAR1 constructs (generous

391 gifts from Kazuko Nishikura at The Wistar Institute, Philadelphia) into pLVX-hygromycin

392 vectors (Cho et al., 2003).

393 Cell proliferation and Focus Formation Assays

For cell proliferation assays, $2-5 \times 10^{4}$ cells were plated in triplicate in six-well plates.

395 Cells were trypsinized, harvested and counted using a hemocytometer or the Cello Cell counter 396 every 24 hours for 4 days post-plating. For the focus formation assay, $3-5 \times 10^{3}$ cells were plated

397 in triplicate in 10-cm cell culture dishes 7-28 days (depending on the cell line: MDA-MB231 and 398 BT549, 7 days; HCC1806, 14 days; SKBR3, 14-21 days; T47D, 21 days; MDA-MB468,

399 CAMA1 and MCF7, 28 days) post-plating until foci became visible. Cells were washed with 400 PBS twice, fixed with 100\% methanol, dried, and stained with Giemsa staining reagent (Sigma 401 Aldrich). Stained plates were scanned and surface areas occupied by cell foci were measured 402 using ImageJ software (NIH, Bethesda, MD).

\section{Soft agar transformation assay}

Equal volumes of $2 \mathrm{X}$ concentrated DMEM culture media and 1\% noble-agar solution

405 (made with sterile cell-culture-grade water) were mixed to make $0.5 \%$ agar-media solution and 406 plated in the bottom of six-well plates. Equal volumes of $2 \mathrm{X}$ concentrated DMEM culture media 407 and $0.6 \%$ noble-agar solution were mixed to make $0.3 \%$ agar-media solution for cell suspension. $408 \quad 2-5 \times 10^{4}$ cells were suspended in $0.3 \%$ agar-media solution and layered, in triplicate, onto the 409 bottom layer. Cells were fed with fresh media every 7 days and incubated in $37^{\circ} \mathrm{C}$ for $21-30$ 
410 days, before being stained with $0.005 \%$ crystal violet and examined under a microscope.

411 Colonies bigger than $100 \mu \mathrm{M}$ in diameter were manually counted.

412 Mammary gland orthopedic implantation

The abilities of human breast cancer cell lines to form tumors in vivo were evaluated by

414 performing mammary gland orthopedic implantation as described previously (Brenot et al.,

415 2018). Immuno-deficient NOD scid gamma (NSG) female mice at 6-8 week-old were purchased

416 from Jackson Laboratory (Bar Harbor, ME) and used for this experiment. 1-3X10 ${ }^{6}$ cells were

417 harvested and resuspended in PBS, mixed with standard base-membrane Matrigel Matrix

418 (Corning, MA, USA) at 1:1 volume ratio, and kept at $4^{\circ} \mathrm{C}$ until implantation. In total $100 \mu 1$ of

419 cells-Matrigel solutions were injected into the right inguinal mammary glands of NSG mice,

420 which were monitored closely to observe tumor formation. Mice were euthanized before tumors

421 in control groups reached 2 cubic $\mathrm{cm}$ in size, and palpable tumors were dissected from the mice

422 for weight measurement. All animal-related experimental procedures were performed in

423 compliance with the guidelines given by the American Association for Accreditation for

424 Laboratory Animal Care and the U.S. Public Health Service Policy on Human Care and Use of

425 Laboratory Animals. All animal studies were approved by the Washington University

426 Institutional Animal Care and Use Committee (IACUC) in accordance with the Animal Welfare

427 Act and NIH guidelines (Protocol 20160916)

428 Statistical analysis

429 Unless otherwise stated, the two-tailed unpaired Student t test was performed for

430 statistical analysis. All in vitro and in vivo data are reported as the mean \pm SD unless stated

431 otherwise, Statistical analyses were performed using GraphPad Prism. P values are as indicated:

$432 *, \mathrm{p}<0.05 ; * *, \mathrm{p}<0.01 ; * * *, \mathrm{p}<0.001 ; * * * *, \mathrm{p}<0.0001 ;$ n.s., not significant. 


\section{Polysome profiling}

Either MDA-MB231 or HCC1806 cells were treated with $100 \mu \mathrm{g} / \mathrm{mL}$ cycloheximide in growth media for 5 minutes at $37^{\circ} \mathrm{C}$. The cells were washed with ice-cold 1x PBS containing $100 \mu \mathrm{g} / \mathrm{mL}$ cycloheximide prior to harvesting by scraping. The cells were lysed in polysome lysis buffer $(20 \mathrm{mM}$ Tris $\mathrm{pH} 7.26,130 \mathrm{mM} \mathrm{KCl}, 10 \mathrm{mM} \mathrm{MgCl}, 0.5 \% \mathrm{NP}-40,0.2 \mathrm{mg} / \mathrm{mL}$ heparin, $200 \mathrm{U} / \mathrm{mL}$ RNasin, $2.5 \mathrm{mM}$ DTT, 1x HALT, $100 \mu \mathrm{g} / \mathrm{mL}$ cycloheximide, 0.5\% sodium deoxycholate) for 20 minutes on ice prior to clarification at $8000 \mathrm{~g}$ for 10 minutes at $4{ }^{\circ} \mathrm{C}$. The absorbance at $260 \mathrm{~nm}$ was determined for each lysate. An equal number of A260 units for each lysate was overlaid on a 10-50\% sucrose gradient $(10 \mathrm{mM}$ Tris $\mathrm{pH} 7.26,60 \mathrm{mM} \mathrm{KCl,} 10 \mathrm{mM}$ $\mathrm{MgCl}_{2}, 2.5 \mathrm{mM}$ DTT, $0.2 \mathrm{mg} / \mathrm{mL}$ heparin, $10 \mu \mathrm{g} / \mathrm{mL}$ cycloheximide). The gradients were subjected to centrifugation at 30,000 RPM for 3 hours at $4{ }^{\circ} \mathrm{C}$. The absorbance at $254 \mathrm{~nm}$ was measured along the gradient using a fractionation system (Teledyne ISCO).

\section{Analysis of rRNA integrity}

For analysis of rRNA integrity, total RNA isolated from cells of interest as described above was denatured in 1x RNA Loading Dye (NEB) containing $100 \mathrm{ng} / \mu \mathrm{L}$ ethidium bromide by incubation at $65{ }^{\circ} \mathrm{C}$ for 10 minutes. The denatured RNA was resolved on a $1.5 \%$ denaturing formaldehyde agarose gel as described previously (Rio, 2015).

\section{Analysis of CCLE RNAseq Data and ADAR1 Dependency}

Raw CCLE RNaseq count data from breast cancer cell lines were normalized by the 'cpm' function of 'edgeR'(Robinson et al., 2010). From the cpm values z-scores were determined for each gene across all cell lines. To determine 'ISG Core Score' or 'ISG Score' we calculated the median z-score of previously identified 'Core ISGs' (Liu et al., 2019) or all ISGs defined by the GSEA/mSigDB hallmark gene set collection 
(HALLMARK_INTERFERON_ALPHA_RESPONSE and

HALLMARK_INTERFERON_GAMMA_RESPONSE) (Liberzon et al., 2015) . Molecular

subtypes of breast cancer cell lines were defined previously (Marcotte et al., 2016).

459

460 in the main text and figures or supplemental information.

\section{Analysis of TCGA RNAseq Data} formula. TCGA samples were defined previously (Lehmann et al., 2016).

\section{Data and Code Availability} Cancer Cell Line Encyclopedia and is available online at https://portals.broadinstitute.org/ccle/data. Dependency data Institute FireBrowse and is available online at http://firebrowse.org/.

Unnormalized RSEM values were normalized by the 'cpm' function of edgeR(Robinson et al., 2010). From the cpm values modified z-scores were determined using the following

$$
z=\frac{[(\text { cpm gene } X \text { in breast cancer sample })-(\text { mean gene } X \text { in normal })]}{(\text { standard deviation } X \text { in normal })}
$$

We calculated 'ISG Core Score' and 'ISG Score' as described above. Molecular subtypes of

CCLE RNAseq count data (CCLE_RNAseq_genes_counts_20180929.gct.gz,

CCLE_RNAseq_rsem_transcripts_tpm_20180929.txt.gz) were obtained from the Broad Institute

(D2_combined_gene_dep_scores.csv, Achilles_gene_effect.csv) were obtained from Broad Institute DepMap Portal and is available on at https://depmap.org/portal/download/. TCGA breast cancer RNAseq (illuminahiseq_rnaseqv2-RSEM_genes, illuminahiseq_rnaseqv2RSEM_isoforms_normalized) and clinical data (Merge_Clinical) were obtained from the Broad

\section{Immunohistochemistry}


Human breast formalin fixed paraffin embedded tissue array sections $(5 \mu \mathrm{m})$ on positively

479 charged slides were obtained from US Biomax Inc. (BC081116d). For immunohistochemistry,

480 sections were stained using a Bond RXm autostainer (Leica). Briefly, slides were baked at $65^{\circ} \mathrm{C}$

481 for 15min and automated software performed dewaxing, rehydration, antigen retrieval, blocking,

482 primary antibody incubation, post primary antibody incubation, detection (DAB), and

483 counterstaining using Bond reagents (Leica). Samples were then removed from the machine,

484 dehydrated through ethanols and xylenes, mounted and cover-slipped. An antibody for ADAR1-

485 p150 (Abcam ab126745) was diluted 1:100 in Antibody Diluent (Leica). 


\section{References}

487

488

489

490

491

492

493

494

495

496

497

498

499

500

501

502

503

504

505

506

507

508

509

510

511

512

513

514

515

516

517

518

519

520

521

522

523

524

525

526

527

528

529

530

531

ADEMUYIWA, F. O., TAO, Y., LUO, J., WEILBAECHER, K. \& MA, C. X. 2017. Differences in the mutational landscape of triple-negative breast cancer in African Americans and Caucasians. Breast Cancer Res Treat, 161, 491-499.

ANANTHARAMAN, A., GHOLAMALAMDARI, O., KHAN, A., YOON, J. H., JANTSCH, M. F., HARTNER, J. C., GOROSPE, M., PRASANTH, S. G. \& PRASANTH, K. V. 2017. RNA-editing enzymes ADAR1 and ADAR2 coordinately regulate the editing and expression of Ctn RNA. FEBS Lett, 591, 2890-2904.

ANDERS, C. K., ABRAMSON, V., TAN, T. \& DENT, R. 2016. The Evolution of TripleNegative Breast Cancer: From Biology to Novel Therapeutics. Am Soc Clin Oncol Educ Book, 35, 34-42.

BINOTHMAN, N., HACHIM, I. Y., LEBRUN, J. J. \& ALI, S. 2017. CPSF6 is a Clinically Relevant Breast Cancer Vulnerability Target: Role of CPSF6 in Breast Cancer. EBioMedicine, 21, 65-78.

BRENOT, A., KNOLHOFF, B. L., DENARDO, D. G. \& LONGMORE, G. D. 2018. SNAIL1 action in tumor cells influences macrophage polarization and metastasis in breast cancer through altered GM-CSF secretion. Oncogenesis, 7, 32.

BROCKWELL, N. K., OWEN, K. L., ZANKER, D., SPURLING, A., RAUTELA, J., DUIVENVOORDEN, H. M., BASCHUK, N., CARAMIA, F., LOI, S., DARCY, P. K., LIM, E. \& PARKER, B. S. 2017. Neoadjuvant Interferons: Critical for Effective PD-1Based Immunotherapy in TNBC. Cancer Immunol Res, 5, 871-884.

CHO, D. S., YANG, W., LEE, J. T., SHIEKHATTAR, R., MURRAY, J. M. \& NISHIKURA, K. 2003. Requirement of dimerization for RNA editing activity of adenosine deaminases acting on RNA. J Biol Chem, 278, 17093-102.

CHUNG, H., CALIS, J. J. A., WU, X., SUN, T., YU, Y., SARBANES, S. L., DAO THI, V. L., SHILVOCK, A. R., HOFFMANN, H. H., ROSENBERG, B. R. \& RICE, C. M. 2018. Human ADAR1 Prevents Endogenous RNA from Triggering Translational Shutdown. Cell, 172, 811-824 e14.

DAVE, B., GONZALEZ, D. D., LIU, Z. B., LI, X., WONG, H., GRANADOS, S., EZZEDINE, N. E., SIEGLAFF, D. H., ENSOR, J. E., MILlER, K. D., RADOVICH, M., KARINAETROVIC, A., GROSS, S. S., ELEMENTO, O., MILLS, G. B., GILCREASE, M. Z. \& CHANG, J. C. 2017. Role of RPL39 in Metaplastic Breast Cancer. J Natl Cancer Inst, 109.

DOHERTY, M. R., CHEON, H., JUNK, D. J., VINAYAK, S., VARADAN, V., TELLI, M. L., FORD, J. M., STARK, G. R. \& JACKSON, M. W. 2017. Interferon-beta represses cancer stem cell properties in triple-negative breast cancer. Proc Natl Acad Sci US A, 114, 13792-13797.

DOHERTY, M. R., PARVANI, J. G., TAMAGNO, I., JUNK, D. J., BRYSON, B. L., CHEON, H. J., STARK, G. R. \& JACKSON, M. W. 2019. The opposing effects of interferon-beta and oncostatin-M as regulators of cancer stem cell plasticity in triple-negative breast cancer. Breast Cancer Res, 21, 54.

FORYS, J. T., KUZMICKI, C. E., SAPORITA, A. J., WINKELER, C. L., MAGGI, L. B., JR. \& WEBER, J. D. 2014. ARF and p53 coordinate tumor suppression of an oncogenic IFNbeta-STAT1-ISG15 signaling axis. Cell Rep, 7, 514-26.

FUMAGAlli, D., GACQUER, D., ROTHE, F., LEFORT, A., LIBERT, F., BROWN, D., KHEDDOUMI, N., SHLIEN, A., KONOPKA, T., SALGADO, R., LARSIMONT, D., 
POLYAK, K., WILlARD-GALlO, K., DESMEDT, C., PICCART, M., ABRAMOWICZ, M., CAMPBELL, P. J., SOTIRIOU, C. \& DETOURS, V. 2015. Principles Governing A-to-I RNA Editing in the Breast Cancer Transcriptome. Cell Rep, 13, 277-89.

GANNON, H. S., ZOU, T., KIESSLING, M. K., GAO, G. F., CAI, D., CHOI, P. S., IVAN, A. P., BUCHUMENSKI, I., BERGER, A. C., GOLDSTEIN, J. T., CHERNIACK, A. D., VAZQUEZ, F., TSHERNIAK, A., LEVANON, E. Y., HAHN, W. C. \& MEYERSON, M. 2018. Identification of ADAR1 adenosine deaminase dependency in a subset of cancer cells. Nat Commun, 9, 5450.

GARRIDO-CASTRO, A. C., LIN, N. U. \& POLYAK, K. 2019. Insights into Molecular Classifications of Triple-Negative Breast Cancer: Improving Patient Selection for Treatment. Cancer Discov, 9, 176-198.

GEORGE, C. X., RAMASWAMI, G., LI, J. B. \& SAMUEL, C. E. 2016. Editing of Cellular Self-RNAs by Adenosine Deaminase ADAR1 Suppresses Innate Immune Stress Responses. J Biol Chem, 291, 6158-68.

GUMIREDDY, K., LI, A., KOSSENKOV, A. V., SAKURAI, M., YAN, J., LI, Y., XU, H., WANG, J., ZHANG, P. J., ZHANG, L., SHOWE, L. C., NISHIKURA, K. \& HUANG, Q. 2016. The mRNA-edited form of GABRA3 suppresses GABRA3-mediated Akt activation and breast cancer metastasis. Nat Commun, 7, 10715.

HAN, L., DIAO, L., YU, S., XU, X., LI, J., ZHANG, R., YANG, Y., WERNER, H. M. J., ETEROVIC, A. K., YUAN, Y., LI, J., NAIR, N., MINELLI, R., TSANG, Y. H., CHEUNG, L. W. T., JEONG, K. J., ROSZIK, J., JU, Z., WOODMAN, S. E., LU, Y., SCOTT, K. L., LI, J. B., MILLS, G. B. \& LIANG, H. 2015. The Genomic Landscape and Clinical Relevance of A-to-I RNA Editing in Human Cancers. Cancer Cell, 28, 515-528.

ISHIZUKA, J. J., MANGUSO, R. T., CHERUIYOT, C. K., BI, K., PANDA, A., IRACHETAVELlVE, A., MILlER, B. C., DU, P. P., YATES, K. B., DUBROT, J., BUCHUMENSKI, I., COMSTOCK, D. E., BROWN, F. D., AYER, A., KOHNLE, I. C., POPE, H. W., ZIMMER, M. D., SEN, D. R., LANE-RETICKER, S. K., ROBITSCHEK, E. J., GRIFFIN, G. K., COLLINS, N. B., LONG, A. H., DOENCH, J. G., KOZONO, D., LEVANON, E. Y. \& HAINING, W. N. 2019. Loss of ADAR1 in tumours overcomes resistance to immune checkpoint blockade. Nature, 565, 43-48.

KUNG, C. P., MAGGI, L. B., JR. \& WEBER, J. D. 2018. The Role of RNA Editing in Cancer Development and Metabolic Disorders. Front Endocrinol (Lausanne), 9, 762.

LAN, Q., PEYVANDI, S., DUFFEY, N., HUANG, Y. T., BARRAS, D., HELD, W., RICHARD, F., DELORENZI, M., SOTIRIOU, C., DESMEDT, C., LORUSSO, G. \& RUEGG, C. 2019. Type I interferon/IRF7 axis instigates chemotherapy-induced immunological dormancy in breast cancer. Oncogene, 38, 2814-2829.

LEHMANN, B. D., JOVANOVIĆ, B., CHEN, X., ESTRADA, M. V., JOHNSON, K. N., SHYR, Y., MOSES, H. L., SANDERS, M. E. \& PIETENPOL, J. A. 2016. Refinement of Triple-Negative Breast Cancer Molecular Subtypes: Implications for Neoadjuvant Chemotherapy Selection. PLoS One, 11, e 0157368.

LI, Y., BANERJEE, S., GOLdSTEIN, S. A., DONG, B., GAUGHAN, C., RATH, S., DONOVAN, J., KORENNYKH, A., SILVERMAN, R. H. \& WEISS, S. R. 2017. Ribonuclease L mediates the cell-lethal phenotype of double-stranded RNA editing enzyme ADAR1 deficiency in a human cell line. Elife, 6. 
LI, Z., OKONSKI, K. M. \& SAMUEL, C. E. 2012. Adenosine deaminase acting on RNA 1 (ADAR1) suppresses the induction of interferon by measles virus. J Virol, 86, 3787-94.

LIBERZON, A., BIRGER, C., THORVALDSDÓTTIR, H., GHANDI, M., MESIROV, J. P. \& TAMAYO, P. 2015. The Molecular Signatures Database (MSigDB) hallmark gene set collection. Cell Syst, 1, 417-425.

LIDDICOAT, B. J., PISKOL, R., CHALK, A. M., RAMASWAMI, G., HIGUCHI, M., HARTNER, J. C., LI, J. B., SEEBURG, P. H. \& WALKLEY, C. R. 2015. RNA editing by ADAR1 prevents MDA5 sensing of endogenous dsRNA as nonself. Science, 349, 1115-20.

LIU, H., GOLJI, J., BRODEUR, L. K., CHUNG, F. S., CHEN, J. T., DEBEAUMONT, R. S., BULLOCK, C. P., JONES, M. D., KERR, G., LI, L., RAKIEC, D. P., SCHLABACH, M. R., SOVATH, S., GROWNEY, J. D., PAGLIARINI, R. A., RUDDY, D. A., MACISAAC, K. D., KORN, J. M. \& MCDONALD, E. R., 3RD 2019. Tumor-derived IFN triggers chronic pathway agonism and sensitivity to ADAR loss. Nat Med, 25, 95102.

LO, P. K., YAO, Y., LEE, J. S., ZHANG, Y., HUANG, W., KANE, M. A. \& ZHOU, Q. 2018. LIPG signaling promotes tumor initiation and metastasis of human basal-like triplenegative breast cancer. Elife, 7.

MANNION, N. M., GREENWOOD, S. M., YOUNG, R., COX, S., BRINDLE, J., READ, D., NELLAKER, C., VESELY, C., PONTING, C. P., MCLAUGHLIN, P. J., JANTSCH, M. F., DORIN, J., ADAMS, I. R., SCADDEN, A. D., OHMAN, M., KEEGAN, L. P. \& O'CONNELL, M. A. 2014. The RNA-editing enzyme ADAR1 controls innate immune responses to RNA. Cell Rep, 9, 1482-94.

MARCOTTE, R., SAYAD, A., BROWN, K. R., SANCHEZ-GARCIA, F., REIMAND, J., HAIDER, M., VIRTANEN, C., BRADNER, J. E., BADER, G. D., MILLS, G. B., PE'ER, D., MOFFAT, J. \& NEEL, B. G. 2016. Functional Genomic Landscape of Human Breast Cancer Drivers, Vulnerabilities, and Resistance. Cell, 164, 293-309.

MCARTHUR, H. 2019. Combining Chemotherapy and Immunotherapy for the Treatment of Triple-Negative Breast Cancer. Oncology (Williston Park), 33, 137-40.

MCFARLAND, J. M., HO, Z. V., KUGENER, G., DEMPSTER, J. M., MONTGOMERY, P. G., BRYAN, J. G., KRILL-BURGER, J. M., GREEN, T. M., VAZQUEZ, F., BOEHM, J. S., GOLUB, T. R., HAHN, W. C., ROOT, D. E. \& TSHERNIAK, A. 2018. Improved estimation of cancer dependencies from large-scale RNAi screens using model-based normalization and data integration. Nat Commun, 9, 4610.

MEYERS, R. M., BRYAN, J. G., MCFARLAND, J. M., WEIR, B. A., SIZEMORE, A. E., XU, H., DHARIA, N. V., MONTGOMERY, P. G., COWLEY, G. S., PANTEL, S., GOODALE, A., LEE, Y., ALI, L. D., JIANG, G., LUBONJA, R., HARRINGTON, W. F., STRICKLAND, M., WU, T., HAWES, D. C., ZHIVICH, V. A., WYATT, M. R., KALANI, Z., CHANG, J. J., OKAMOTO, M., STEGMAIER, K., GOLUB, T. R., BOEHM, J. S., VAZQUEZ, F., ROOT, D. E., HAHN, W. C. \& TSHERNIAK, A. 2017. Computational correction of copy number effect improves specificity of CRISPR-Cas9 essentiality screens in cancer cells. Nat Genet, 49, 1779-1784.

NAKANO, M., FUKAMI, T., GOTOH, S. \& NAKAJIMA, M. 2017. A-to-I RNA Editing Upregulates Human Dihydrofolate Reductase in Breast Cancer. J Biol Chem, 292, 48734884. 
654

655

656

657

658

659

PAZ-YAACOV, N., BAZAK, L., BUCHUMENSKI, I., PORATH, H. T., DANANGOTTHOLD, M., KNISBACHER, B. A., EISENBERG, E. \& LEVANON, E. Y. 2015. Elevated RNA Editing Activity Is a Major Contributor to Transcriptomic Diversity in Tumors. Cell Rep, 13, 267-76.

PENG, X., XU, X., WANG, Y., HAWKE, D. H., YU, S., HAN, L., ZHOU, Z., MOJUMDAR, K., JEONG, K. J., LABRIE, M., TSANG, Y. H., ZHANG, M., LU, Y., HWU, P., SCOTT, K. L., LIANG, H. \& MILLS, G. B. 2018. A-to-I RNA Editing Contributes to Proteomic Diversity in Cancer. Cancer Cell, 33, 817-828 e7.

PEROU, C. M. 2011. Molecular stratification of triple-negative breast cancers. Oncologist, 16 Suppl 1, 61-70.

PESTAL, K., FUNK, C. C., SNYDER, J. M., PRICE, N. D., TREUTING, P. M. \& STETSON, D. B. 2015. Isoforms of RNA-Editing Enzyme ADAR1 Independently Control Nucleic Acid Sensor MDA5-Driven Autoimmunity and Multi-organ Development. Immunity, 43, 933-44.

PUJANTELL, M., RIVEIRA-MUNOZ, E., BADIA, R., CASTELLVI, M., GARCIA-VIDAL, E., SIRERA, G., PUIG, T., RAMIREZ, C., CLOTET, B., ESTE, J. A. \& BALLANA, E. 2017. RNA editing by ADAR1 regulates innate and antiviral immune functions in primary macrophages. Sci Rep, 7, 13339.

RIO, D. C. 2015. Denaturation and electrophoresis of RNA with formaldehyde. Cold Spring Harb Protoc, 2015, 219-22.

ROBINSON, M. D., MCCARTHY, D. J. \& SMYTH, G. K. 2010. edgeR: a Bioconductor package for differential expression analysis of digital gene expression data. Bioinformatics, 26, 139-40.

SAGREDO, E. A., BLANCO, A., SAGREDO, A. I., PEREZ, P., SEPUlVEDAHERMOSILLA, G., MORALES, F., MULLER, B., VERDUGO, R., MARCELAIN, K., HARISMENDY, O. \& ARMISEN, R. 2018. ADAR1-mediated RNA-editing of 3'UTRs in breast cancer. Biol Res, 51, 36 .

SILVERMAN, R. H., SKEHEL, J. J., JAMES, T. C., WRESCHNER, D. H. \& KERR, I. M. 1983. rRNA cleavage as an index of $\operatorname{ppp}(\mathrm{A} 2$ ' $\mathrm{p}) \mathrm{nA}$ activity in interferon-treated encephalomyocarditis virus-infected cells. $J$ Virol, 46, 1051-5.

SNELL, L. M., MCGAHA, T. L. \& BROOKS, D. G. 2017. Type I Interferon in Chronic Virus Infection and Cancer. Trends Immunol, 38, 542-557.

SONG, I. H., KIM, Y. A., HEO, S. H., PARK, I. A., LEE, M., BANG, W. S., PARK, H. S., GONG, G. \& LEE, H. J. 2017. ADAR1 expression is associated with tumour-infiltrating lymphocytes in triple-negative breast cancer. Tumour Biol, 39, 1010428317734816.

WAKS, A. G. \& WINER, E. P. 2019. Breast Cancer Treatment: A Review. JAMA, 321, 288-300. 
bioRxiv preprint doi: https://doi.org/10.1101/2020.01.31.928911; this version posted February 2, 2020. The copyright holder for this preprint (which was not certified by peer review) is the author/funder, who has granted bioRxiv a license to display the preprint in perpetuity. It is made available under aCC-BY-NC-ND 4.0 International license.

Figure 1

A) 660 661

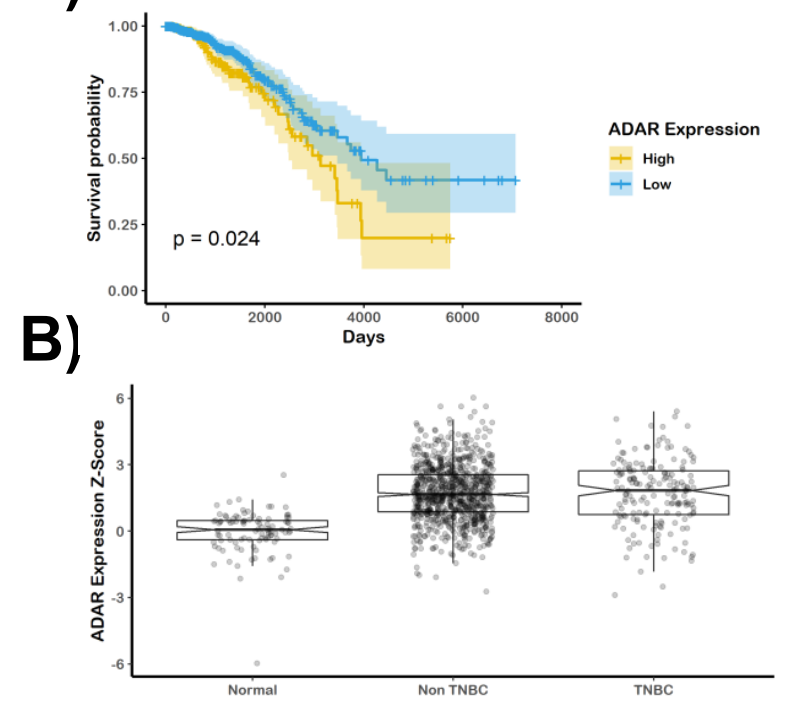

D)

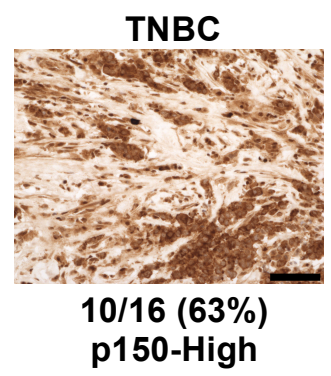

E)

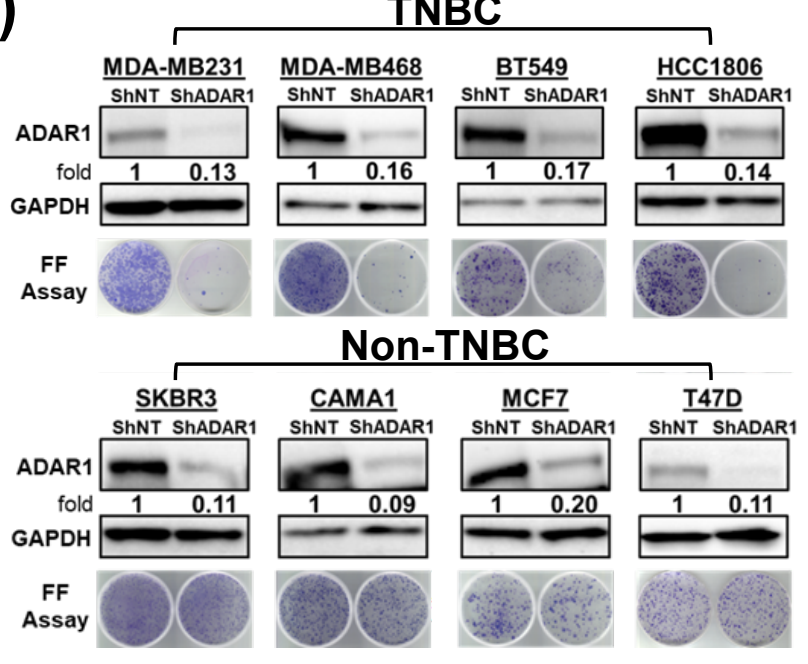

H)

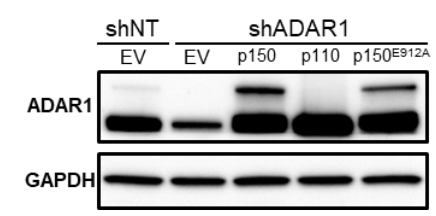

I)

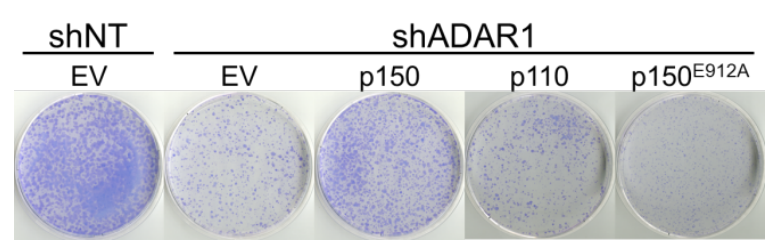

C)

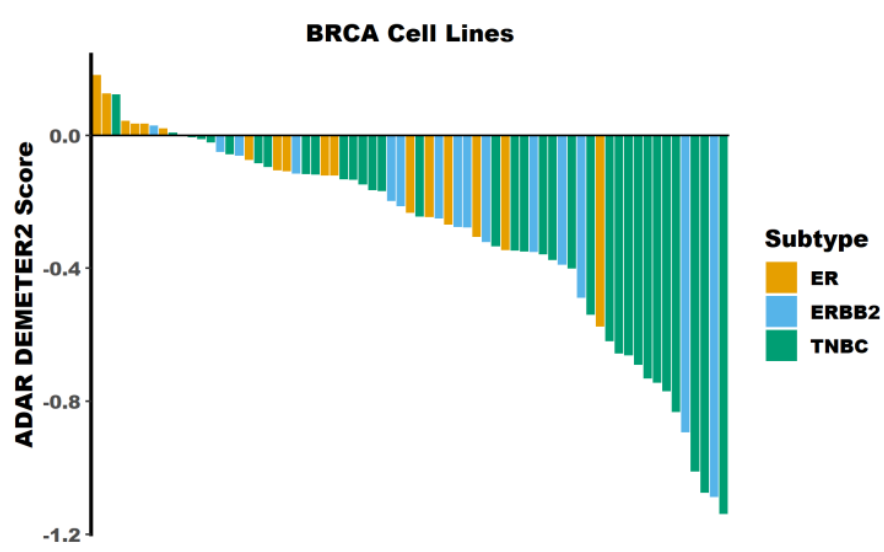

F)

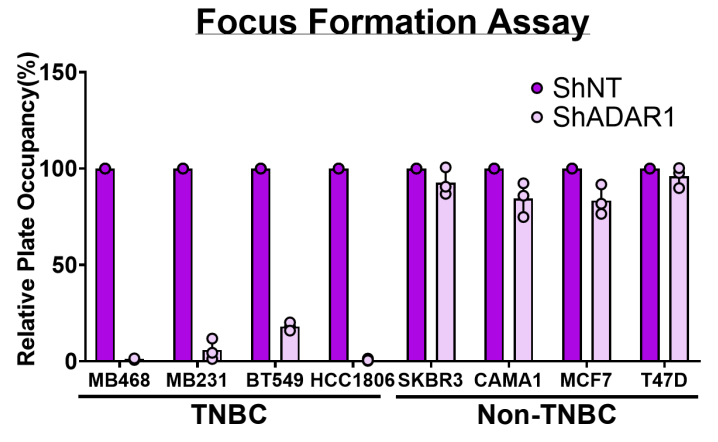

G)
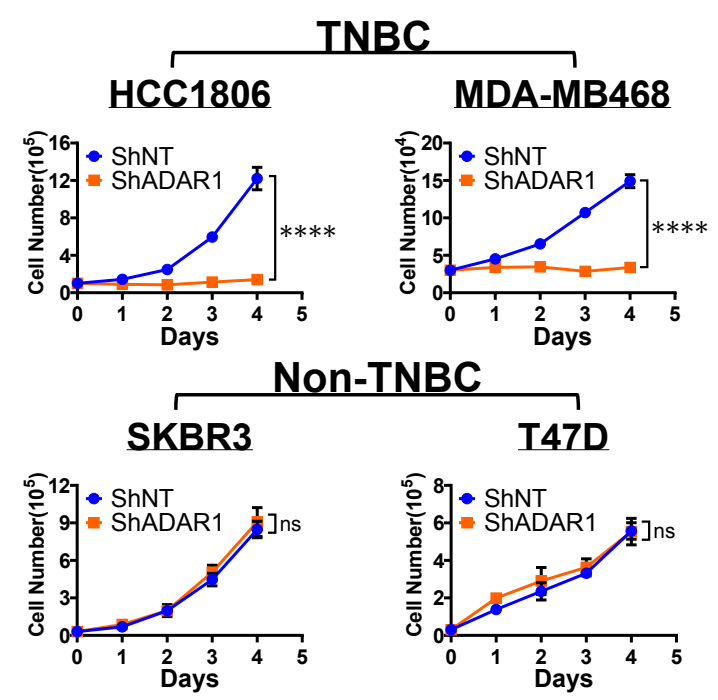

J)

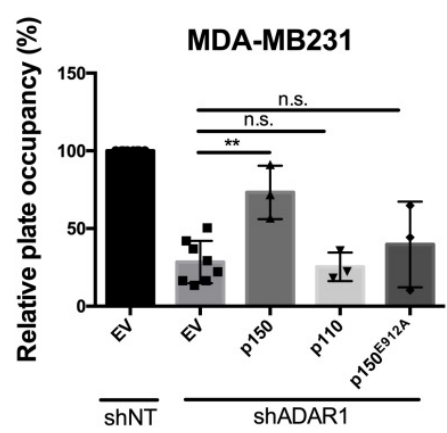


662

663
A)

TNBC

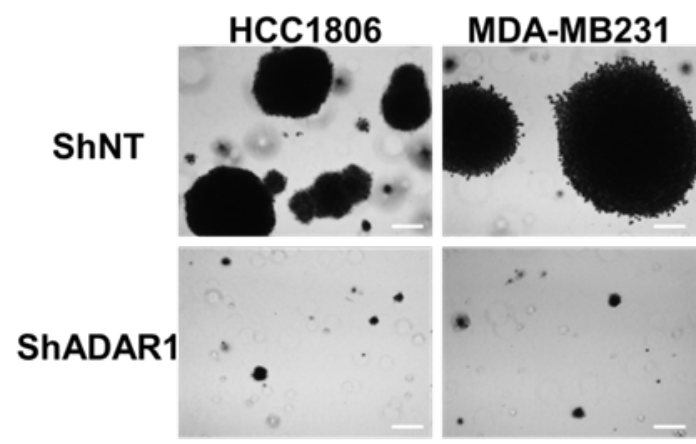

C)

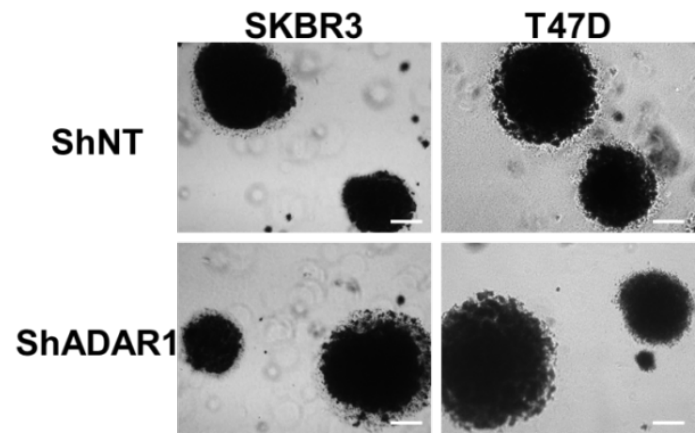

E)

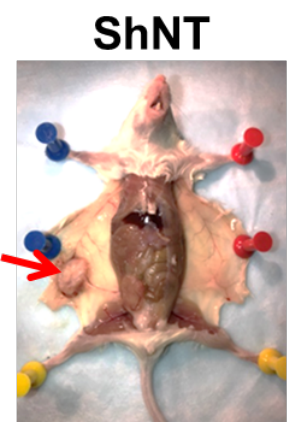

F)

MDA-MB468
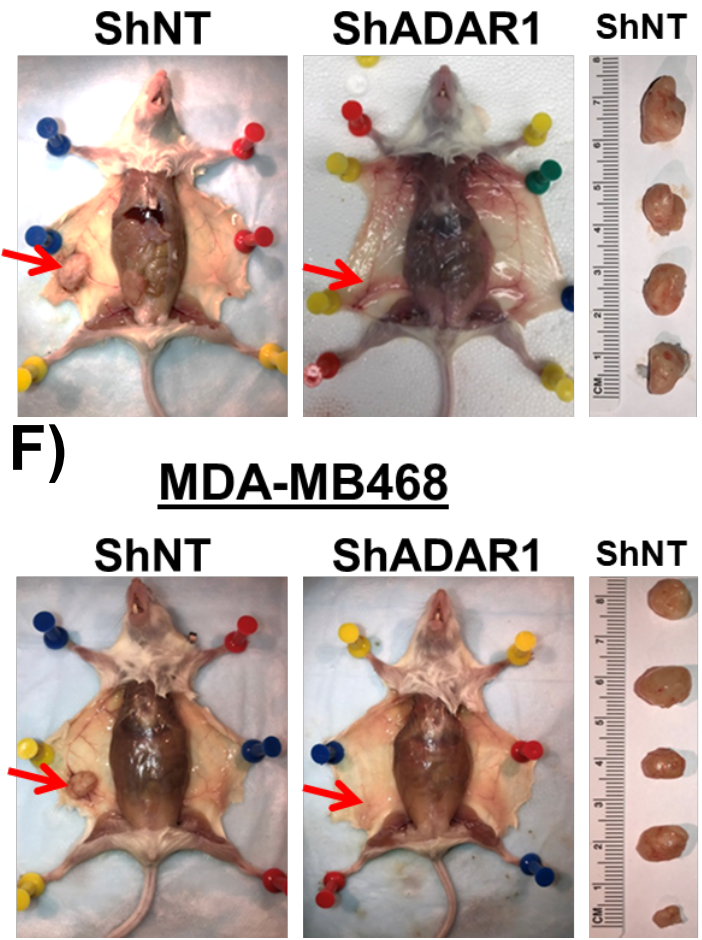

B)

TNBC
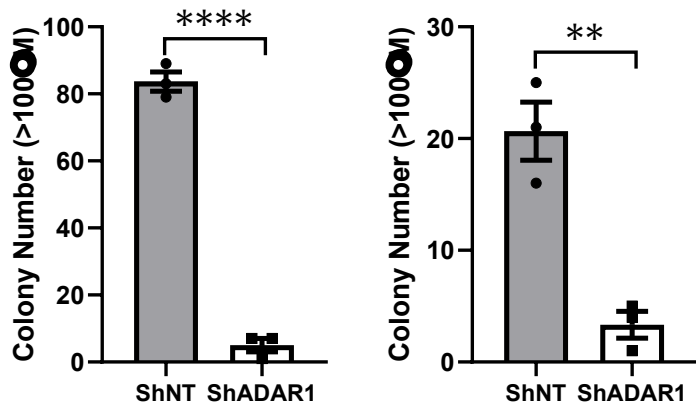

D)

Non-TNBC
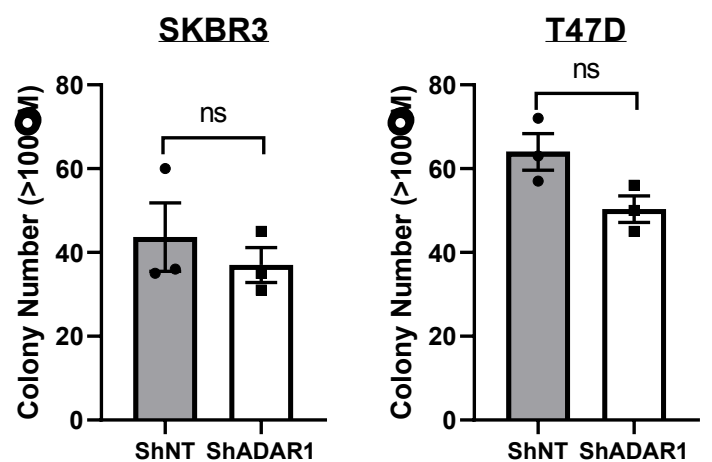

G)

H)
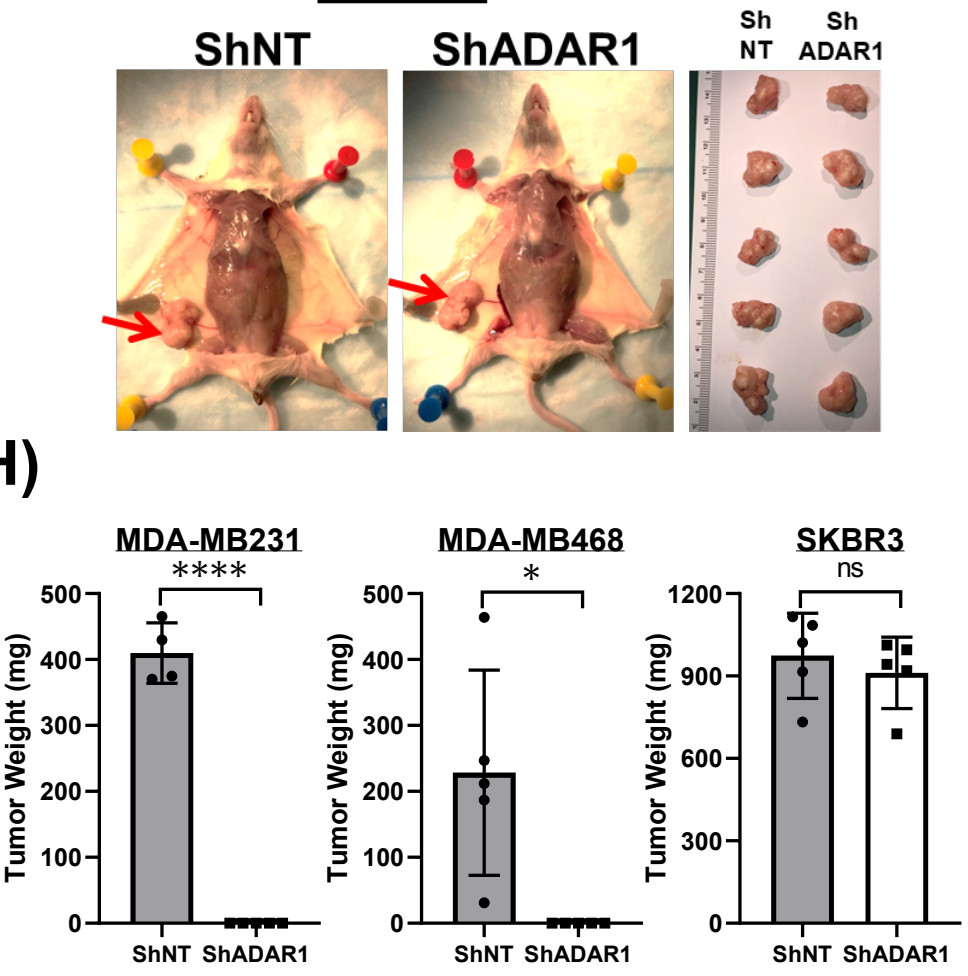
bioRxiv preprint doi: https://doi.org/10.1101/2020.01.31.928911; this version posted February 2, 2020. The copyright holder for this preprint (which was not certified by peer review) is the author/funder, who has granted bioRxiv a license to display the preprint in perpetuity. It is made available under aCC-BY-NC-ND 4.0 International license.

Figure 3

665

A)

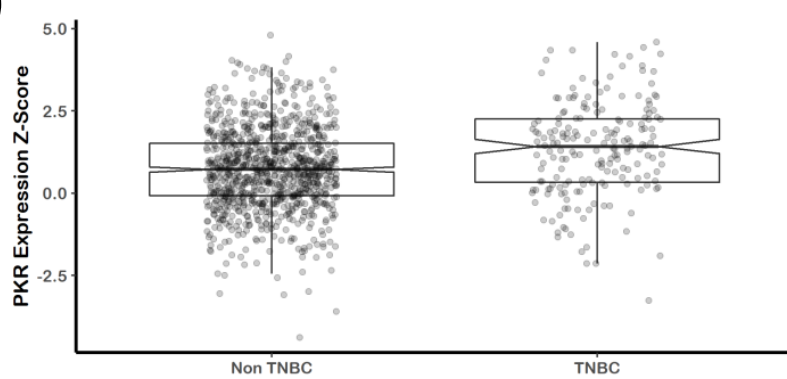

C)
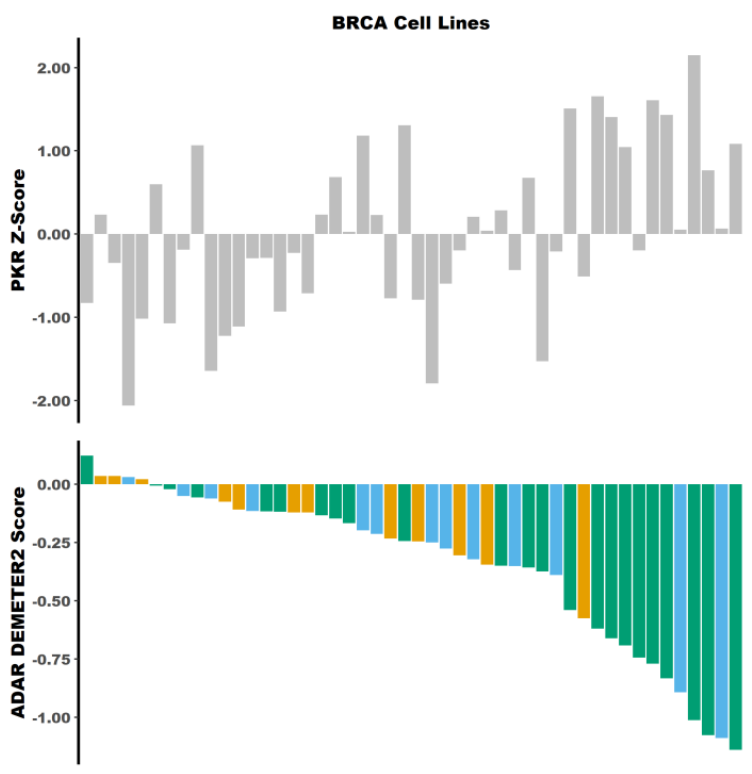

ER ERBB2 — TNBC

F)

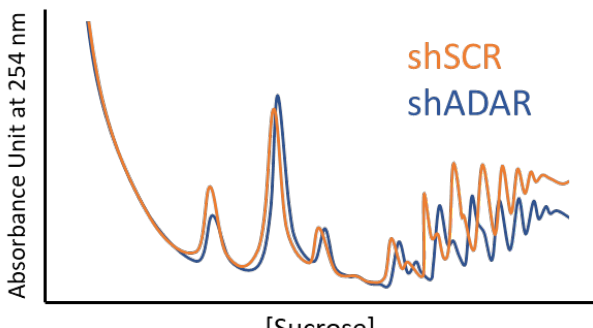

B)

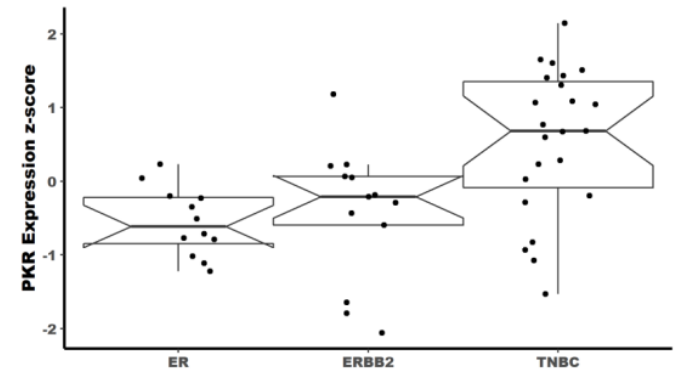

D)

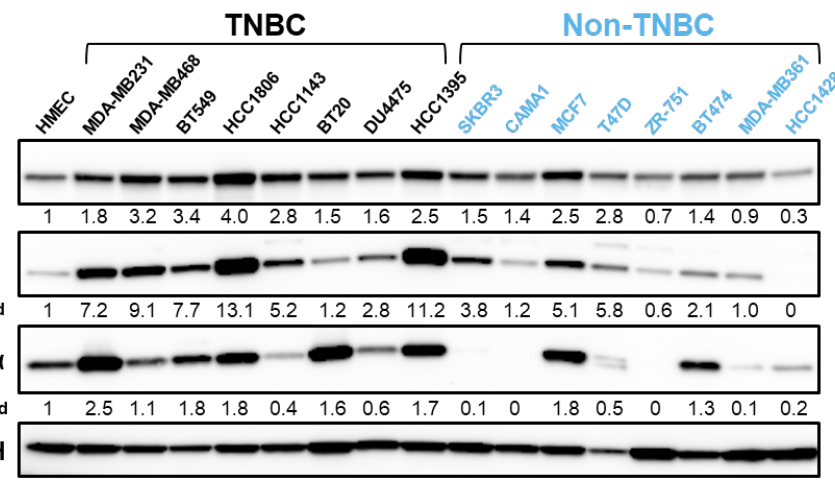

E)

TNBC

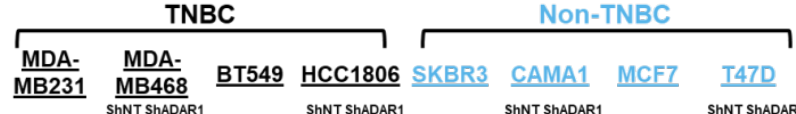

ShNT ShADAR1 $^{\text {ShNT ShADAR1 }}$ ShNT ShADAR1 $^{\text {ShNT ShADAR1 }}{ }_{\text {SHNT ShADAR1 }}{ }^{\text {ShNT ShADAR1 }}{ }_{\text {ShNT ShADAR1 }}{ }^{\text {ShNT ShADAR1 }}$

PKR

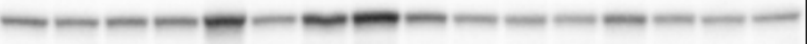

p-PKR

p-PKR fold

$p$-elF2 $\alpha$

$\beta$-tubulin

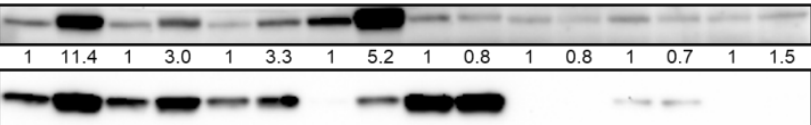

G)

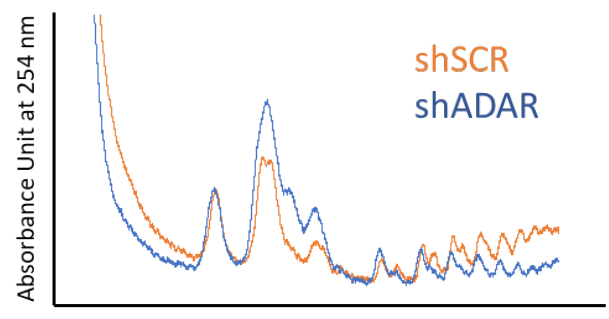

[Sucrose] 
A)

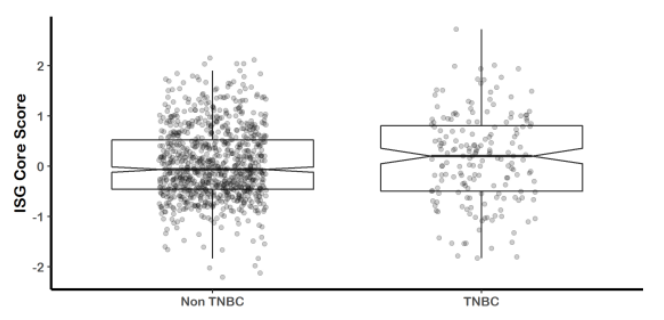

B)

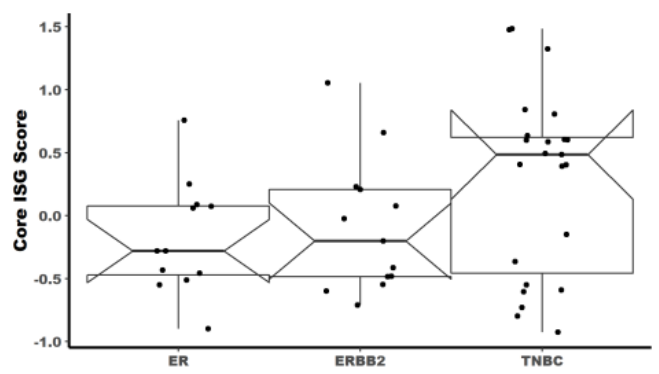

D)

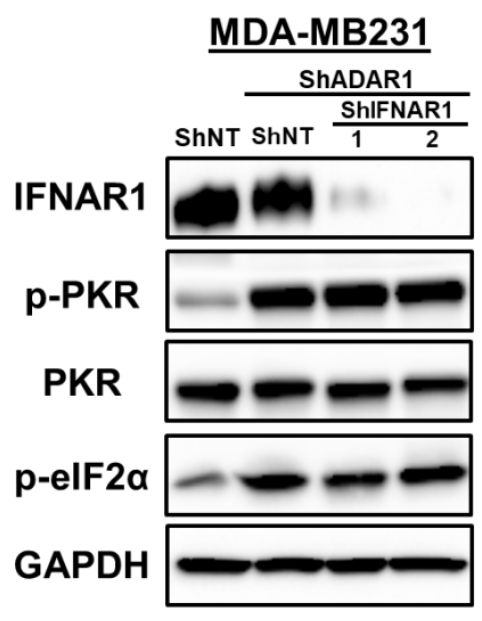

C)
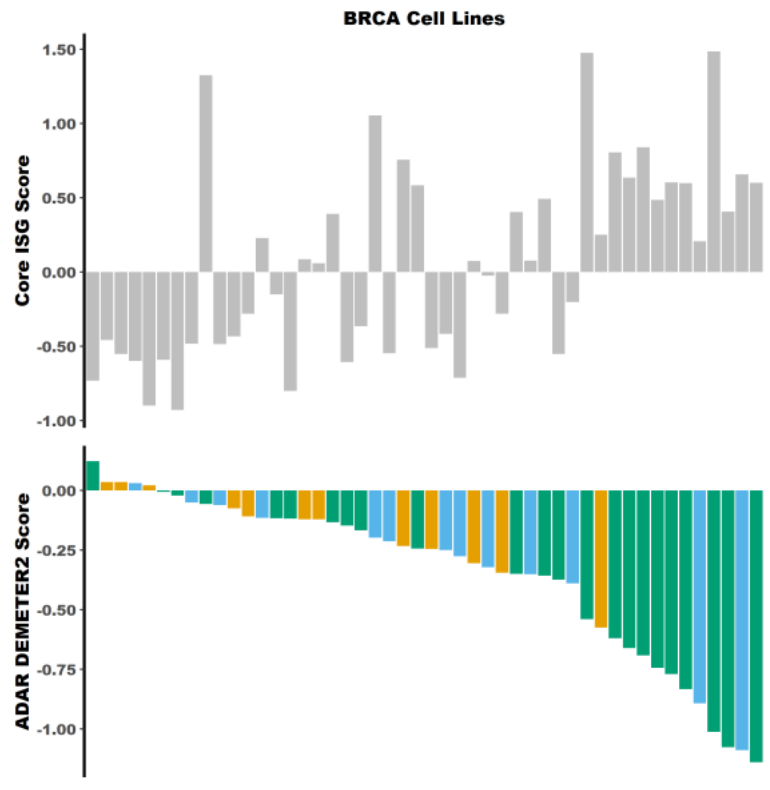

ER ERBB2

E)

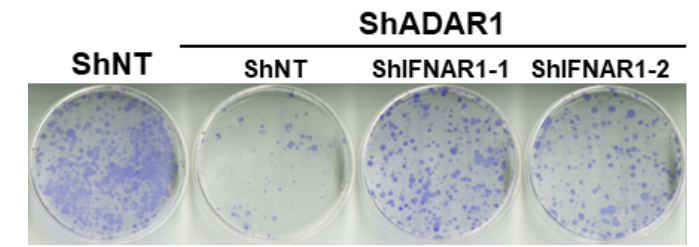

F)

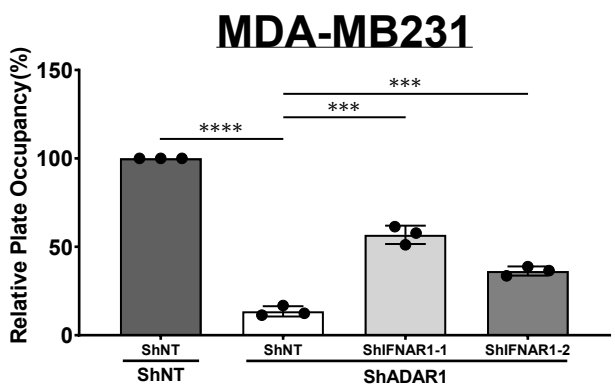

